\title{
Class Teachers - Their Thinking and Reasoning in the Context of Creating a Favourable Classroom Social Climate by Means of the Methods of Personal and Social Education
}

\author{
Zuzana Geršicová ${ }^{*}$
}

\begin{abstract}
The paper deals with class teachers' thinking and reasoning processes and the possibilities of influencing teachers' ability to create a favourable classroom social climate. This paper describes personal and social education as one of the means and methods of such influencing. The results of the research carried out indicate that teachers have a very high opinion regarding their ability to create a favourable classroom social climate. The issues of personal and social education in the work of a class teacher are the topic of the project KEGA 002DTI-4/2013 being solved by a team of professionals at Dubnica Institute of Technology in Dubnica nad Váhom.

Key words: class teacher, personal and social education, favourable classroom social climate, perceived self-efficacy.
\end{abstract}

\section{Introduction}

Today's youth enter their lives equipped with rich theoretical knowledge but they are not prepared for the most important thing they need in their everyday lives. Young people are not able to communicate effectively, to cope with conflicts nor to solve them.

They cannot cope with everyday problems, are not skilled to organize their lives, time, gifts and talents, dreams nor desires. They do not know how to deal with their inclusion into the system of social roles in life. One of the possible ways of improving this situation is personal and social education in schools leading to the development of personal, individual prerequisites of people for living with

Zuzana Geršicová, Dubnica Institute of Technology in Dubnica nad Váhom, Dubnica nad Váhom, Slovakia; gersicova@dti.sk 


\section{Acta Technologica Dubnicae \\ volume 6, 2016, issue 1}

themselves and other people in the current social context, to the development of social (interactional, relations) skills for living with other people and to the development of ethical prerequisites for living in the society and in this world as such (Gymerská, Kožuch, \& Záškvarová, 2009, p. 7). And here it is necessary to emphasize the need for professional educational work on the side of teachers, especially class teachers, who play the specificational and integrational role within educational programs. The educational encyclopaedia (Pedagogický slovník, 1985, p. 458) defines a class teacher as a teacher authorized by the director of a school to a school class both form educational and administrative aspects. The personal qualities, job description and professional self-efficacy of a class teacher can be summed up as follows: gets and gathers information about pupils and processes them as a part of complex assessment, monitors their school success and behaviour in the class, supervises pupil's school attendance, perceives them in the context of their family environment. From the above follows that class teachers, besides knowledge from pedagogy and psychology, need a huge amount of creativity, ideas, exercises and methods for developing young people's values and, at the same time, for creating a positive classroom social climate.

\section{Class teachers and sessions with the class teacher}

Class teachers lead their pupils throughout the whole process of schooling starting from primary and ending at secondary schools. They are the first contact persons in case of questions, unclarities and problems. Class teachers are responsible for the activities of a school class, organize its working routine, and work with class documentation. They must ensure the equality in relationships in the school class as well as equally good learning conditions for all its members. They help students with completing all their duties and, at the same time, supervise them. They are responsible for the discipline and following the school rules but the rights of pupils must not be restricted neither by their school mates nor their teachers. From the above, it is clear that being a class teacher is not an easy thing. The expectations on the side of the school management, pupils, pupils' parents and their colleagues are high. Based on our personal experience, we tried to formulate the most important tasks in the work of a class teacher and divided them into five basic fields:

- Coordination of the educational work in the classroom, cooperation with parents, legal representatives, representatives of various organizations and institutions;

- Creation of hygienically appropriate conditions for education;

- Preservation of security and of pupils' health;

- Working with pedagogical documentation;

- Creation of a favourable classroom social climate. 


\section{Acta Technologica Dubnicae \\ volume 6, 2016, issue 1}

The specifics of class teachers' work at various levels of education should not be forgotten about. There are some differences between the status of class teachers in primary and lower secondary schools. Especially the differences in the amount of time spent with their pupils is visible. In case of primary school teachers, class teachers spend the whole school day with their class, while lower secondary school teachers who only teach their subject in the class (which can be 2-5 lessons per week depending on the number of lessons in the timetable) and meet their pupils only during their regular group sessions with the class teacher. It can have a negative impact on the creation of a closer relationship between teachers and their pupils. Of course, it is important to take into account the specifics of younger school-age children, their greater openness, responsiveness and their willingness to follow the set rules. With pupils of older school-age, rebelliousness, denying authority and attempts to fulfil their need for personal self-realization appear.

In the school environment, class teachers can get to know their pupils better during the regular group sessions with the class teacher. Sessions with the class teacher provide space for the class teachers' direct educational impact on pupils and for increasing the quality of communication with their legal representatives. The goal of the sessions with the class teacher is solving educational problems and activities of the particular class. The precondition for doing so, according to Hlásna $(2005,2008,2011)$, is having information about the existing social relationships in the class.

According to the Decree of the Ministry of Education of the Slovak Republic No. 320/2008 Coll. on Primary School as amended by the Decree No. 224/2011 Coll., regular group sessions with the class teacher in which students and teachers discuss general class and school matters are included in school timetables. The length of a group session with the class teacher is 45 minutes (one teaching period) and is not included in the total number of pupil's lessons nor in the teachers' class time per week. Class teachers can decide about the form and the content of the session based on their own needs and the requirements of the school management. By this decision, teachers were given freedom but, at the same time, the question of the content of the sessions with the class teacher has arisen.

\section{The current state of the issues of teachers' personal and social education in Slovakia}

Preparedness for everyday life is not only a sum of general knowledge that opens young people the path to further studies, but it represents help in the sphere of life orientation and adequate reactions in various life situations. If we take a deeper look, we, for sure, find out that the acquisition of life competencies 


\section{Acta Technologica Dubnicae \\ volume 6, 2016, issue 1}

is underestimated in comparison with knowledge competencies in the Slovak school system. Personal and social education was implemented in the British curriculum for children aged 5 to 16 in 2003. It includes the field of relationships and communities on both local and global levels, sexual education, moral education, environmental education and spiritual education. In the Czech Republic, personal and social education has been mandatory in the curriculum of every primary school since 2007. It is included in the national curriculum for primary education as a cross-cutting theme. Individual parts of every crosscutting theme are mandatory and it is up to the school where and how pupils get in touch with them during their school attendance. It can be a part of the educational subjects, projects, courses and various activities. It is usually realized by means of experiential learning. Personal and social education is focused on personality development, development of social skills and moral values. In the Slovak Republic, new state educational programs on all school levels based on the international classification ISCED were introduced by the Act No. 245/2008 Coll. on Education (the school act). Personal and social education is included in all levels of education starting from ISCED 0 and ending at ISCED 3 as a compulsory cross-cutting theme. Cross-cutting themes deal with topical issues, they serve as a guideline for prevention and solution of problems, and, at the same time, help to deepen basic knowledge with an emphasis on its application. They should contribute to broadening students' minds, help to acquire certain attitudes, values, help in decision making. They interconnect various fields of knowledge, contribute to the complexity of students' education, they have a positive impact on the process of the development and improvement of pupils' key competencies. They can be taught within school subjects, but also in the form of courses or as individual elective subjects (Act No. 245/2008 Coll. on Education). The cross-cutting theme Personal and Social Development develops the human potential of pupils, prepares them for a full and responsible life. It means not only academic development of pupils, but also the development of personal and social skills that support the academic development.

The aim is to:

- Develop pupils' self-reflection, self-knowledge, self-respect and selfconfidence; and taking responsibility for their actions, personal life, selfeducation; to teach pupils how to apply their rights but also to respect the opinions, needs and rights of others.

- Support the prevention of social-pathological phenomena by its content.

- Help students develop and maintain personal integrity.

- Develop high quality interpersonal relationships.

- Develop the social skills necessary for life and cooperation (according to Štátny pedagogický ústav, 2012). 


\section{Acta Technologica Dubnicae \\ volume 6, 2016, issue 1}

Within this cross-cutting theme, also human rights education as well as family education are applied (Tamášová, 2006, p. 13). The theme crosses all the fields of education and responds to the current needs of pupils. It is necessary to use suitable activities, model situations, discussions, games and other interactive methods with all the themes.

\section{Project}

Personal and Social Education as a Part of Class Teachers' Lifelong Learning is a project being solved by pedagogues from the Dubnica Institute of Technology in Dubnica nad Váhom (project leader: Z. Geršicová). The main purpose of the project is to react on the need for a broader implementation of personal and social education realized by class teachers into primary and secondary schools and to make their job easier by means of handbooks on how to manage group sessions with the class teacher and teacher-parent meetings. The team of investigators aims to achieve this by working out and testing methodological handbooks in practice and their subsequent corrections, after which handbooks will be introduced into practice.

Based on the above stated, it is evident that personal and social education should be introduced to our schools. This type of education is included in the project in the part of testing methodological handbooks in practice. It is not a research project but an application project focusing on the practical skills of class teachers in the field of personal and social education as well as methodological support by fulfilling its goals in practice. The project has the potential of further development and application in other research tasks that can follow after testing and introducing the methodological handbooks into practice. One of the possible solutions is the project of continuous education for class teachers in the form of socio-educational training which can help teachers to learn more about the individual methods and techniques of personal and social education and their realization with a group of pupils. A better knowledge of the class offers the teachers the opportunity to evaluate the relationships in the classroom and the classroom climate better.

\section{Favourable social climate}

Several authors have defined the notion of school climate. For the purposes of our paper, we have chosen three of them.

According to Průcha, Walterová and Mareš (1995), it is the long term socioemotional state characterized by attitudes, relationships, and pupils' emotional responses to various classroom situations. 


\section{Acta Technologica Dubnicae \\ volume 6, 2016, issue 1}

Gavora (1999) defines classroom climate as the extent to which a pupil is satisfied in the class, whether the pupils have good relationships in the class, what is the level of competition between them and what is the degree of class cohesion.

According to Mareš (1998), as for its content, the notion of classroom climate includes the established procedures, perception, experiencing, evaluation and reactions by all the participants (the teacher, all the pupils in the class, groups of pupils within the particular class, and individual pupils) to what has happened, is happening or will happen in the future in the classroom. He accentuates that the perception and interpretation of the climate by the participants themselves, i.e. the subjective aspects of school climate and not what the climate objectively is like, is accentuated. The reason is clear: for reflection, taking positions, action and the evaluation of such actions, the subjective view of the participants on the school class is important.

The common feature of all the definitions is the emotional side of the mutual relationships in the classroom and their subjective evaluation by individuals participating in the creation of classroom social climate. Their view on their ability to objectively change the current social climate is subjective as well.

These statements lead us to conclude that the success of a teacher's work with a school class and in the classroom is influenced by:

- The teacher's and pupils' positive approach to what is happening in the classroom;

- efficiency of mutual communication;

- knowledge of the social-psychological phenomena of the school class;

- their diagnostics by means of appropriate methods using a suitable diagnostic tool;

- collecting the results and formulating findings;

- suggestion of suitable methods and interventions;

- realization of these interventions and evaluation of the results.

One of the task of a class teacher, as mentioned above, is to create a positive classroom social climate. We understand this notion as minimization of fear and jitters on the side of pupils, motivation to learning, and creation of optimal conditions for developing personal relationships. The positiveness of classroom social climate is, in our understanding, divided into five dimensions - a high degree of satisfaction and cohesion of pupils in a school class on one hand and a minimum of conflicts, low degree of competition between pupils and adequacy of requirements on pupils on other hand. The personal development of pupils should be accentuated and their assessment should be more complex. A positive classroom social climate is not created only by a positive approach of teachers to 


\section{Acta Technologica Dubnicae \\ volume 6, 2016, issue 1}

pupils but also by their participation in the life around them and tutoring them, encouraging and supporting them in mutual help.

A positive social climate is determined by mutual trust between the class teacher and pupils; participation of pupils in decision making; evaluation, motivation and encouragement on the side of the teacher and the schoolmates; and decency and fairness as for the participation in class life. It makes a difference whether the social climate is objectively favourable or only perceived so by its participant. In the next part of the paper, we focus on gaining information regarding the perception of the professional self-efficacy of teachers in the process of creating a positive classroom social climate.

\section{Professional self-efficacy as perceived by pupils}

Class teachers have their own ways of class management (based on their personal qualities). It is reflected in the behaviour of pupils, social climate and their actions in the classroom. For this reason, we focused on the perception of self-efficacy in relation to the process of creation of a positive social climate by class teachers. According to the general definition of perceived self-efficacy, it is a characteristic feature which has an influence on success or failure in every human activity. One thing is to have all the predispositions for the completion of a particular task but to believe that we can solve the tasks is another one. Selfefficacy is a part of the socio-cognitive theory by Albert Bandura. Bandura (1997) defines self-efficacy as an individual's beliefs regarding their capacity to organize and execute behaviour successfully in order to achieve one's goals.

Individuals with a high degree of perceived self-efficacy are more independent, resilient and they see themselves more positively. They set themselves more demanding goals, are more persistent in endeavour and give up in case of failure less frequently. The quality of their performances is increasing and they feel contentment. They are sure of their abilities in a particular field, they trust themselves, they perceive difficult tasks and overcoming obstacles as challenges. They take responsibility for their behaviour and manage their lives with an ease.

Individuals with a low degree of perceived self-efficacy are psychically vulnerable, have problems with handling stressful situations and often have a tendency to depression. Their self-confidence is low, they do not trust their own abilities. They run away from solving problems, feel incompetent to deal with them and easily give up. Their feeling of helplessness brings them to self-pity and to the effort to show themselves and the others how a problem or task cannot be solved without any real argument. Failure is perceived as the lack of own abilities. Their belief that they do not have power over their own lives and are 


\section{Acta Technologica Dubnicae \\ volume 6, 2016, issue 1}

not capable to manage them is very strong. They lack decisiveness, are easy to influence and to manipulate with.

"Perceived self-efficacy is an important regulatory factor of many activities. We consider it an extremely important characteristic feature of a teacher. In this context, we discuss perceived professional self-efficacy. Self-image is a very strong regulatory factor of personality, that is why we deal with the beliefs of teachers, not their opinions." (Gavora, 2011, p. 90) In the teaching practice, perceived self-efficacy is defined as teachers' beliefs concerning their own capacity to influence pupils' results, increase motivation, to improve the quality of performance and the perceived personal self-efficacy of students. Teachers' perceived professional self-efficacy is a serious issue connected with teachers' characteristics that have an impact on their thinking and reflection, decision making, planning and managing all the classroom activities.

Such features of perceived self-efficacy as described above can be observed with teachers, too. Gavora (2009) says that we can distinguish between two spheres of the impact related to teachers' perceived professional self-efficacy. One of them is the impact on the assessment of own capacity to influence pupils' development and the other one is the evaluation of the possibilities to change the educational process and to overcome some less favourable external factors (family environment, low abilities of the pupil). Both factors are evaluated by teachers separately. The relationship between these factors has been researched on, e.g. by Tschannen-Morgan and Hoy (2001), and Gavora (2009, 2011).

Teachers with a high perceived professional self-efficacy can organize the educational process better, plan activities on a higher level, they are enthusiastic and diligent. They are resistant to the pressure of the environment and are not afraid of solving problems. They pay more attention to weaker students. They are more open to new ideas, not afraid to experiment with innovative methods of work (problem solving, students' individual projects, group work). Persistence is showed in cases when the educational process does not progress according to the planned steps and in time that teachers dedicate to pupils by searching for appropriate solutions. According to our opinion, it has a strong impact on the classroom social climate.

\section{Questionnaire research - "What am I able to do for the creation of a favourable classroom social climate?"}

In the last decades, observations and examination of the classroom social climate have come to the fore. For class teachers, it is very important to be familiar with the situation in the classroom and be able to progressively respond to the current situation. Our research brings information about teachers' evaluation of own 


\section{Acta Technologica Dubnicae \\ volume 6, 2016, issue 1}

capacity to participate in creating a positive classroom social climate. A more detailed description of the process of construction and the structure of the questionnaire can be found in the scholarly article by Geršicová (2012a).

\section{Research sample}

The research sample consisted of 106 class teachers from primary schools who completed the questionnaire in two regions of Slovakia. One of them was a primary school in Trnava and the other one a primary school in Levice district. The research sample was selected based on the researchers' possibilities and the willingness of the school management and teachers to participate in the research. All the teachers were informed that the gathered data would be used exclusively for the purposes of our research. Based on the demographic data included in the questionnaire, the structure of the research sample is showed in Table 1. In the final evaluation, demographic data related to teachers' qualifications to teach at the particular school level, the number of school classes, and the number of students in one school class are not included in the analysis. We have decided to do so as no statistical significance was found between such smaller groups of respondents during the process of data processing.

Table 1

Composition of the research sample

\begin{tabular}{llll}
\hline Variables & & $\mathrm{n}$ & $\%$ \\
\hline Gender & Female & 94 & 88.7 \\
& Male & 12 & 11.3 \\
School level & Primary & 38 & 35.8 \\
& Lower secondary & 60 & 56.6 \\
& Missing data & 8 & 7.5 \\
\hline
\end{tabular}

Source: Author

\section{Data analysis}

The higher score one achieves in our questionnaire, the higher one's perceived self-efficacy is. The questionnaire contains six-level scales. Their median is 3.5.

The arithmetic mean of the whole research sample reaches the value 5.04, which highly exceeds the median and is very close to the statement "I am always able". Based on this finding, we must assume that teachers trust themselves as for their skill to create a positive classroom social climate. It is clear that it is the 


\section{Acta Technologica Dubnicae \\ volume 6, 2016, issue 1}

teachers' subjective evaluation, not the objective reality regarding their professional self-efficacy. A teacher's real level of self-efficacy can be observed when solving conflicts and problem situations in the classroom and establishing a creative working environment. In the process of creating a positive climate, teachers' trust in themselves is very important. It would be interesting to confront our findings with the evaluation of classroom social climate by pupils. One of the options is to make an interview with the pupils of the class teachers, focusing on the real skills of the particular class teacher in the process of creating a positive classroom climate. The questionnaire method could be used for an inquiry on the evaluation of the classroom social climate and the obtained results could be compared with the results of our questionnaire focusing on teachers' perceived self-efficacy in relation to their capacity to create a favourable classroom climate. Based on our experiences, we can state that the results of the comparison between class teachers and their pupils concerning their evaluation of the classroom social climate would not be very positive for teachers. A research with the same research problem showed that teachers often overrate or underrate the individual dimensions of the classroom social climate compared with students.

The lowest achieved score was 3.04 in item 29 "To have favourite students, who inform me about what is going on in the class". We presume that the teachers expressed their opinions in this item from the moral point of view. We believe that its formulation probably evokes a negative experience with talebearing and betrayal in the class for the most of the participants. Teachers, probably for this reason, consider having such a student in their class to be a failure. Our presumption is supported by the following findings.

The highest achieved score was 5.57, it was achieved in item 9 - "Try to be fair with all the pupils and not to treat them differently". The achieved scores in this item are the proof of the teachers' attempt to give the same attention to all the pupils in the class and not to treat them differently. The moral value of this statement, which can be summed up in one word: "justice" or "equality", is in the perception of teachers, and, in fact, in the perception of the majority of people, built on the hierarchy of moral values and is very high. Therefore, we think that such a high level of perceived self-efficacy of teachers in managing a class is influenced by this fact. In support of our statement, we can mention another finding - the achieved score in item 20 - "To be fair when solving conflicts between pupils.". If we compare the gathered data, we find out that it is the second highest achieved score. 


\section{Acta Technologica Dubnicae \\ volume 6, 2016, issue 1}

\section{Differences between male and female teachers}

Based on the demographic data, the differences between female and male teachers were compared and the findings are worth to mention. The findings show that female teachers achieved higher scores than male teachers, what we had not presumed (Table 2). It means that women rated their perceived professional self-efficacy to create a positive school social climate higher than men. This result showed statistically significant on the level of 5\%. It is necessary to add that the sample contained only 10 male teachers which is a very small number to make more complex conclusions from this finding.

The results of a similar, but a more complex research on Slovak primary school teachers' perceived professional self-efficacy undertaken by Gavora (2011) by means of the OSTES questionnaire show that, similarly to our research, women achieved higher scores than men. In this case, the results were not statistically significant.

Table 2

Questionnaire results according to gender

\begin{tabular}{lllll}
\hline & $\mathrm{n}$ & AP & SD & $\begin{array}{l}\text { Statistical } \\
\text { significance }\end{array}$ \\
\hline Women & 84 & 5.09 & 0.54 & $\mathrm{p}<0.50$ \\
Men & 10 & 4.70 & 0.56 & \\
\hline
\end{tabular}

Source: Author

\section{Results according to the school level}

The results of the comparison based on the school level at which the participating teachers work, are interesting, too. They are shown in Table 3. Slightly higher scores were achieved by primary school teachers. If the sizes of the subsamples of respondents are compared, we must admit that the sample of primary school teachers was a bit smaller that the sample of lower secondary school teachers. The statistical significance on the level of $1 \%$ proves a more developed perceived self-efficacy for the creation of a positive classroom social climate with the primary school teachers. We already presumed the probability of this finding in the theoretical basis where we mentioned the differences in and the possibilities of class teachers' work at primary and lower secondary schools in favour of primary school teachers.

Gavora's (2011) research realized by means of OSTES questionnaire did not show any statistical significance when teachers of primary and lower secondary levels were compared. It is declared in the research, that the teachers of both 
levels had a sufficiently developed level of perceived self-efficacy. The sample of primary school teachers was very small.

Table 3

Results according to the school level

\begin{tabular}{lllll}
\hline & $\mathrm{n}$ & $\mathrm{AP}$ & $\mathrm{SD}$ & $\begin{array}{l}\text { Statistical } \\
\text { significance }\end{array}$ \\
\hline Primary level & 35 & 5.30 & 0.52 & $\mathrm{p}<0.10$ \\
Lower secondary level & 52 & 4.92 & 0.53 & \\
\hline
\end{tabular}

Source: Author

A high score in the overall average rating of perceived professional self-efficacy in the process of the creation of a favourable social climate which is very close to the scale statement "I am always able" leads us to the conclusion that the teachers included in our research sample probably evaluated themselves more positively than the reality shows. This statement is supported by the results of our earlier research, in which the classroom climate was evaluated more positively by teachers than by pupils (Geršicová \& Hlásna, 2013).

\section{Conclusion}

As mentioned above, to have certain predispositions is one thing but to believe that we are able to use them to the full extent is another one. Our actions depend to a great degree on our belief that we really can act that way. As it applies in everyday human life, in the teaching practice it applies twice as much. Those teachers who perceive their own self-efficacy as high, usually become successful at work. Teachers participating in our research perceived their professional selfefficacy in the process of creating a positive classroom social climate as relatively high. It is a positive statement but one should not forget that it is their subjective evaluation which varies from reality. It would be interesting to confront the obtained data with the opinions of the participating teachers' pupils. A direct observation of the class teachers' work during the regular group sessions with the class teacher or their actions when dealing with various situations with their pupils, is another option. According to our opinion, observation of the process of personal and social education during the group sessions with the class teacher would have a significant impact on the perception and evaluation of their own competencies in the process of managing classroom life. We believe that only then their real professionality would be manifested. 


\section{Acta Technologica Dubnicae \\ volume 6, 2016, issue 1}

\section{References}

Bandura, A. (1997). Self-Efficacy: The exercise of control. New York: Freeman.

Bennacer, H. (2000). How the socioecological characteristics of the classroom affect academic achievement. European Journal of Psychology of Education, 15(2), 173-189.

Cangelosi, J. S. (1994). Strategie ř́zeni tř́dy. Praha: Portál.

Dutková, K., \& Medlenová, J. (2007). Sprievodca triedneho učitel'a. Bratislava: Raabe.

Eraut, M. (2000). Design of Initial Teacher Education. International Journal of Educational Research, 33(5), 453-456.

Fraser, B. J., \& Fisher, D. L. (1986). Using Short Forms of Classroom Climate Instruments to Assess and Improve Classroom Psychosocial Environment. Journal of Research in Science Teaching, 5, 387-413.

Gavora, P. (2009). Profesijná zdatnost' vnímaná učitel’om. Adaptácia výskumného nástroja. Pedagogická revue, 61(1-2), 19-37. Retrieved from http://www.fedu.uniba.sk/uploads/media/Profesijna_zdatnost_vnimana_ucit elom_Adaptacia_nastroja.pdf

Gavora, P. et al. (2010). Elektronická učebnica pedagogického výskumu. Bratislava: Univerzita Komenského. Retrieved from http://www.emetodologia.fedu.uniba.sk/index.php/kapitoly/spracovanieudajov/vytvorenie-databazy-dat.php?id=i19p1

Gavora, P. (2011). Zist’ovanie profesijnej zdatnosti učitel'a pomocou dotazníka OSTES. PEDAGOGIKA.SK, 2(2), 88-107 Retrieved from http://www.casopispedagogika.sk/studie/gavora-peter-zistovanie-profesijnej -zdatnosti-ucitela-pomocou-dotaznika-ostes.html

Geršicová, Z. (2009). Prístup rodičov k spolupráci so školou. In Poradca riaditel’a školy (pp. 1-10), Bratislava: Raabe.

Geršicová, Z. (2009). Spolupráca a komunikácia medzi školou a rodinou. In Poradca riaditel'a školy (pp. 1-12), Bratislava: Raabe.

Geršicová, Z., Tamášová, V., \& Ivanová, M. (2012). Inovativno obrzovanie na klasnite rkoboditeli v Slovakija prez celija im žibot ot gledna točka na ličnostnoto $\mathrm{i}$ socialno bzpitanie. In Formirane na graždanina $i$ profesionalista $v$ uslovijata na universitetskoto obrazovanie (pp. 45-51), Gabrovo: SU Fakulta pedagogiky i APSS.

Geršicová, Z. (2012a). Myslenie a uvažovanie triedneho učitel’a v kontexte tvorby priaznivej sociálnej klímy triedy. In Učitel’ a jeho vnímanie školy a triedy (pp. 29-49), Bratislava: OZ V4.

Geršicová, Z. (2012b). Osobnostná a sociálna výchova ako prierezová téma vzdelávania na jednotlivých stupňoch škôl v Slovenskej republike. Acta Humanica, 2a, 197-203. Žilina: Fakulta humanitných vied Žilinskej univerzity, Katedra pedagogických štúdií. 


\section{Acta Technologica Dubnicae \\ volume 6, 2016, issue 1}

Geršicová, Z., \& Hlásna, S. (2013). Sociálna klíma triedy v edukačnej teórii a praxi. Brno: Tribun EU s.r.o.

Gymerská, M., Kožuch, B., \& Záškvarová, V. (2009). Ako riešit’ konflikty a ostat' priatel'mi. Bratislava: PERSONA.

Hendriks, R. (2000). Macht es Sinn, die Kinder zur Schule zu schicken? Pädagogische Führung, 11(1), 45-47.

Hlásna, S. (2005). Hodnotenie spokojnosti so životom v škole žiakmi a učitel'mi vo vybraných krajinách. In L. Hrdina (ed), Veda, škola, život (pp. 39-44). Bratislava: Metodicko-pedagogické centrum.

Hlásna, S. (2008). Pozitívne aspekty života žiakov v triede v príprave budúcich učitel'ov základných a stredných škôl. In Pedagogické otázky prípravy učitel'ov (pp. 113-124). Trnava: Univerzita sv. Cyrila a Metoda v Trnave.

Hlásna, S. (2011). Sociálna klíma triedy a kvalita života žiaka v triede. Bratislava: ZF LINGUA.

Horváthová, K. (2003). Metodické riadenie uplatňované v systéme výchovného poradenstva. Bratislava: MPC.

Chomczynska-Miliskiewicz, M. (1994). Tworzenie bezpiecznej atmosfery w klasie. Nowa szkola, 50(10), 600-603.

Kosová, B. (1999). Vedenie triedy - triedny manažment. Naša škola, 2(8), 6-11.

Kratka, J., \& Střelec, S. (2006). Činnosti tř́íního učitele z pohledu vedení škol. In Sborník z konference ČAV Současné metodologické př́stupy a strategie pedagogického výzkumu (pp. 36-44) [CD ROM]. Plzeň: ČAPV.

Lašek, J., \& Mareš, J. (1991). Jak změřit sociální klima třídy. Pedagogická revue, 43(6), 401-410.

Lašek, J. (1997). Klima tříd základních a středních škol a možnosti jeho měření. In Aktuální otázky pedagogiky a psychologie (pp. 73-84). Hradec Králové: Gaudeamus.

Lašek, J. (1991). Klima tříd základních a středních škol a možnosti jeho měření. In Pedagogická interakce a komunikace (pp. 97-105. Hradec Králové.

Mareš, J. (1998). Sociálni klima školní tř́ldy (přehledová studie). Institut pedagogicko - psychologického poradenství ČR. Retrieved from http://klima.pedagogika.cz/trida/doc/Mares_Klima_tridy.pdf

Marek, E. (1997). Udzial komunikacji edukacyjnej nauczycieli w kreowaniu klimatu spolecznego klasy szkolnej. Zycie szkoly, 51(1), 3-8.

Pavlík, O. et al. (1985). Pedagogická encyklopédia Slovenska (I.,II.). Bratislava: Veda SAV.

Petlák, E. (2006). Klíma školy a klíma triedy. Bratislava: IRIS.

Průcha, J., Walterová, \& MAREŠ, J. (1995). Pedagogický slovník. Praha: Portál.

Průcha, J. (2002). Učitel. Současné poznatky o profesi. Praha: Portál.

Průcha, J. et al. (2009). Pedagogická encyklopedie. Praha: Portál.

Spousta, V. (1993). Základní výchovné činnosti tř́dního učitele. Brno: MU.

Tamášová, V. (2006). Teória a prax rodinnej edukácie. Bratislava: AXIMA. 


\section{Acta Technologica Dubnicae \\ volume 6, 2016, issue 1}

Tschannen, M.., \& Hoy, A. W. (2001). Teacher efficacy: capturing an elusive construct. Teaching and Teacher Education, 17, 783-805.

Višňovský, L. (2000). Triedny učitel'. Banská Bystrica: UMB.

Decree of the Ministry of Education of the Slovak Republic No. 320/2008 Coll. on Primary School. Retrieved from http://www.nucem.sk/documents//26/ legislativa/2008_320.pdf

Decree No. 224/2011 Coll. on Primary School. Retrieved from http://www. komoraucitelov.org/clanok-87-vyhlaska-224-2011-z-z-o-zakladnej-skolezmeny.html

Act No. 245/2008 Coll. on Education (the school act). Retrieved from http://www.minedu.sk/data/USERDATA/ATEMY/2008/20080529_NRSR_ skolsky_zakon.pdf

ŠPÚ (2012). Štátny vzdelávaci program pre 1. stupeň základnej školy v Slovenskej republike ISCED 1 - primárne vzdelávanie. Retrieved from http://www.statpedu.sk/files/documents/svp/1stzs/isced1/isced1_spu_uprav a.pdf 